6. Попова А.В., Гриванов Р.И. Транснациональные корпорации как субъект международных экономических отношений. URL: http://www.eduherald.ru/ru/article/view?id=13161

7. Побирченко B.B., Сазонова Г.В. Транснациональный фактор трансформации экономики Украины в условиях глобализации // Культура народов Причерноморья. 2001. № 26. С. 33-37.

8. Цыганков П.А. Международные отношения: учебное пособие. М., 1996.

9. Шагабиева Е.M. Международные неправительственные организации: их виды, особенности, категории и характеристика // Власть. 2010. № 9. С. 94-96.

10. Наумов А.О. Международные неправительственные организации и проблемы глобального управления // Государственное управление. Электронный Вестник. 2013. Вып. 39, авг. С. 49-76.

11. Минасян Г., Восканян А. Зарубежные НПО: механизм влияния на внутреннюю политику в СНГ // Обозреватель - Observer: научно-аналитический журнал. 2013. № 3. С. 6-19.

12. Стеико E.B. «Глобальное управление» и роль неправительственных организаций в его становлении // Общество. Среда. Развитие (Terra Humana). 2012. № 4. C.110-115.

13. Фокина В.В. СМИ как акторы мировой политики // Вестник МГИМО-Университета. 2013. № 1 (28).C. 61-65.

\section{I.S. Alekhina}

Features of Legal Regulation of the Electoral Law Principles in the Constitutions of the CIS Member States

Features of the legal regulation of the principles of universal, equal and direct suffrage, as well as the principles of obligation and periodicity of elections in the constitutions CIS member states are considered. The electoral legal standards to ensure a uniform interpretation and application of these principles are analyzed.

Key words and word-combinations. principles of electoral law, legal regulation of principles, election standards, electoral standards, constitutions, CIS.

Рассматриваются особенности правового регулирования принципов всеобщего, равного, прямого избирательного права, а такжепринципов обязательности и периодичности выборов в конституциях стран СНГ. Анализируются правовые избирательные стандарты, обеспечивающие единообразное понимание и применение данных принципов.

Ключевые слова и словосочетания: принципы избирательного права, правовые избирательные стандарты, конституции, СНГ
DOI 10.22394/1682-2358-2017-1-44-50

Y, $\Delta \mathrm{K} 342.8$

ББК 67.400 .8

\section{И.С. Алёхина}

\section{ОСОБЕННОСТИ}

ПРАВОВОГО РЕГУАИРОВАНИЯ ПРИНЦИПОВ

ИЗБИРАТЕАЬНОГО ПРАВА

В КОНСТИТУЩИЯХ

ГОСУААРСТВ УЧАСТНИКОВ СНГ

\section{$\mathrm{H}$}

основе фундаментальных прав и свобод человека и гражданина в международных Аокументах быми сформулированы важнейшие принципы избирательного права. Их единообразное понимание и применение обеспечивается правовыми избиратемьными стандартами, которые выступают в качестве нормативной основы и одновре- 
менно правовым средством процесса реализации норм избирательного законодательства.

В сферу нашего изучения вошли особенности правового регулирования принщипов всеобщего, равного, прямого избирательного права, обязательности и периодичности выборов, а также правовые избирательные стандарты, обеспечивающие единообразное понимание и применение указанных принципов, закрепленные в Конституџиях государств - участников Содружества Независимых Государств (Аалее государств - участников СНГ). Несомненно, указанный перечень принципов является неполным. Отметим, что в работе не исследуется избирательное законодательство государств участников СНГ.

ЕАинообразное понимание и применение принџипа всеобщего избирательного права обеспечивается, в частности, правовыми избирательными стандартами: избирательными цензами; дополнительными условиями реализации пассивного избирательного права гражАан; ограничениями активного и пассивного избирательного права, связанными с нахождением места жительства гражданина; обеспечением участия в выборах (в голосовании) дмя граждан, находящихся в день голосования на территории иностранных государств; ограничением статуса депутата и выборного должностного миџа; особыми условиями реализации избирательного права военнослужащими [1] .

Проанализировав конститущии государств - участников СНГ, можно сделать вывоА, что основными законами этих государств преАусмотрено введение избирательных цензов (стандарт ограничения активного и пассивного избирательного права), который по своему характеру не явцяется дискриминационным и не противоречит международным обязательствам некоторых государств [2, ст. 18] (например, предоставление пассивного избирательного права гражданам по достижении опредеменного возраста). При указании возраста используются различные формулировки. Так, в отношении глав государств конститущии Республик Азербайджана [3], Армении [4], Бекаруси [5], Казахстана [6], Кыргызстана [7], России [8] установливают, что Президент «может быть избран»; согласно конститущиям Республик Молдова [9], Таджикистана [10] и Украины [11] Президент «избирается».

Конституциями закреплены дополнительные условия реализации пассивного избирательного права, связанные с достижением определенного возраста. Так, в Азербайджане, Армении, Бемаруси, Кыргызстане, России, Таджикистане Конституции содержат формулировку «не моложе 35 мет», в Казахстане «не моложе 40 кет», миџо, «достигшее 35 кет» - в Армении и Украине, "достигшее 40-летнего возраста» - в Момдове. Указание на допустимость установмения максимального возраста «не старше 70 мет» имеется только в Конституции Кыргызской Республики.

Правовой стандарт дополнительных условий реализации пассивного избирательного права также не позволяет одному и тому же мицу занимать выборную Аолжность более установценного количества сроков полряА. 
В конституциях государств - участников СНГ эта норма применима к домжности Президента страны. Например, «одно и то же миџо не может быть избрано на должность Президента более чем два раза полряд» (Армения); «одно и то же мицо не может быть избрано Президентом дважды» (Кыргызстан); «одно и то же миџо не может занимать должность Президента более Авух сроков подряА» (Молдова, Россия); «одно и то же миџо не может быть Президентом более двух сроков подряА» (Таджикистан, Украина). В Беларуси и Казахстане не установлено подобных ограничений. Срок полномочий Президента составляет четыре года в Молдове, пять мет - в Азербайджане, Армении, Бекаруси, Казахстане, Украине, шесть мет - в России, семь мет в ТаАжикистане.

Следует отметить, что согласно Конститущии Азербайджанской Республики в соответствующих главах допускается ограничение пассивного избирательного права как дмя главы государства, так и дмя депутатов парламента. «Президентом Азербайджанской Республики может быть избран... в том числе не судимый за тяжкое преступление, не имеющий обязательств переА Аругими госуАарствами... без двойного гражАанства» [3, ст. 100] . «Не могут быть избраны депутатами Мимли Меджлиса Азербайджанской Республики миџа, имеющие Авойное гражданство, имеющие обязательства переА Аругими государствами, работающие в системе исполнительной или судебной власти, миџа, занимающиеся Аругой оплачиваемой деятельностью, кроме научной, педагогической и творческой, религиозные деятели, миџа, недееспособность которых подтверждается судом, осужденные за тяжкие преступцения, отбывающие наказание в местах Аишения свободы по приговору суда, вступившему в законную силу» [3, ст. 85].

В конституциях Аругих государств нормы, ограничивающие избирательные права граждан, установлены в общих статьях.

Рассмотрим правовой избирательный стандарт, допускающий ограничения активного и пассивного избирательного права, связанные с местом жкительства гражданина. В России ограничение пассивного избирательного права, связанное с нахождением места жительства гражданина на определенной территории Российской Федерации, включая требования к продолжительности и сроку проживания гражданина на данной территории, устанавливаются Конституцией РФ только для Президента Российской Федерации, которым может быть «избран гражАанин... постоянно проживающий в Российской ФеАераџии не менее 10 мет» [8, ст. 81].

В конституциях государств - участников СНГ также есть подобные ограничения, например, «постоянно проживающий свыше 10 мет» в Азербайджане, «постоянно проживающий последние 10 мет» и «последние 10 мет являющийся гражАанином» в Армении, «постоянно проживающий не менее 10 кет непосредственно переА выборами» и гражданин по рождению в Беларуси, «проживающий последние 15 мет» и гражАанин по рождению в Казахстане, «проживающий в совокупности не менее 15 мет» в Кыргызстане, «проживавший или проживающий на территории Республики Молдова не менее 10 мет», «постоянно проживающий не менее 10 мет» в 
России, «постоянно проживающий не менее 10 последних мет» в Таджикистане, «проживающий в течение 10 последних переА Анем выборов мет» на Украине.

Согласно Конституции Армении «законом может устанавливаться право на участие в выборах органов местного самоуправления и местных референдумах миџ, не имеющих гражданство Республики Армения» [4, ст. 30] .

Знание государственного языка требуется в Казахстане (свободное владение), Кыргызстане, Молдове, Таджикистане, Украине.

Необходимость высшего образования установцена в Конституции Азербайджана.

В некоторых странах конституциями предусмотрено ограничение на право участия в выборах дмя определенного круга миц. Согласно Конституции Азербайджана, ограничивается право участия в выборах военнослужащих, судей,

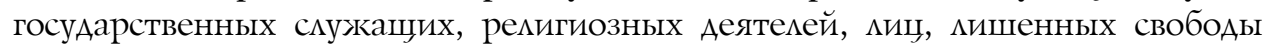

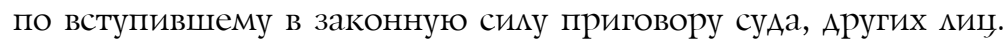

Рассматривая принџип равного избирательного права, можно выделить слеАующие стандарты: равное число голосов у избирателей; обеспечение участия в голосовании, если гражданин не имеет возможности прибыть на избирательный участок по месту его основной регистрации, а также Аця граждан, проживающих за пределами избирательного округа; равные условия выдвижения дия кандидатов; гарантии деятельности зарегистрированного кандидата; ограничения, связанные с Аолжностным ици служебным положением кандидатов; откцонение от правового стандарта территориальной основы выборов для обеспечения представительства коренных и малочисленных народов.

Исследуя конституции государств - участников СНГ, отметим, что выборы здесь проходят на основе равного избирательного права. Например, в Конститущии Республики Беларусь установлено, что «выборы явцяются равными: избиратели имеют равное количество голосов. Кандидаты, избираемые на государственные Аолжности, участвуют в выборах на равных основаниях» [5, ст. 66].

Правовыми избирательными стандартами, обеспечивающими единообразное понимание и применение принципа прямого избирательного права, явцяются: голосование за ици против кандидата (списков кандидатов); состязательность выборов; альтернативность выборов; стандарт представительства.

Альтернативность обеспечивается тем, что число зарегистрированных канАидатов на выборах превышает число установленных мандатов. ОАнако в Конституции Армении предусмотрена возможность избрания Президента на безальтернативных выборах: «...в случае бамлотирования одного кандидата он избирается, если за него проголосовало более половины участников голосования» [4, ст. 51].

В Азербайджане [3, ст. 101], Армении [4, ст. 51], Бекаруси [5, ст. 82], Казахстане [6, ст. 41], Момдове [9, ст. 78] выборы в органы государственной власти и местного самоуправления проходят по той же системе, что и выборы Президента государства. Конституџией Кыргызской Респубцики установцена избирательная система дия парламента Республики [7, ст. 70] . 
Правовыми избирательными стандартами, обеспечивающими еАинообразное понимание и применение принџипа периодичности и обязательности проведения выборов, явцяются: сроки проведения голосования; проведение в установленный день; стандарт, устанавцивающий субъекты назначения выборов; стандарт совмешения выборов; ограничение проведения выборов в условиях военного и (или) чрезвычайного положения.

Анализа конституций государств - участников СНГ выявцяет сроки полномочий главы государства и парламента, в некоторых странах - Ани провеАения выборов глав государств, выборов в парламент. Так, выборы Президента Республики Армения осуществцяются за пятьдесят дней до истечения его полномочий [4, ст. 51]. Выборы Президента Бекаруси назначаются Пацатой представителей не позАнее чем за пять месяцев и проводятся не позАнее чем за два месяџа до истечения срока полномочий предылущего Президента [5, ст. 81]. Выборы Президента Республики Казахстан назначаются на первое воскресенье декабря и не могут совпадать по срокам с выборами нового состава Парламента Республики. Выборы Президента Украины проводятся в последнее воскресенье марта пятого года полномочий Президента Украины. В случае Аосрочного прекращения его полномочий выборы должны состояться в период девяноста Аней со Аня прекращения полномочий. В Республике Азербайджан выборы Президента проводятся «каждые 5 кет в первое воскресенье ноября» [3, ст. 84] .

Конституциями государств - участников СНГ установлен день проведения выборов Парламентов.

Срок полномочий Национацьного собрания Армении начинается с момента созыва первого заседания вновь избранного Национального собрания и завершается в момент созыва первого заседания вновь избранного Национального собрания [4, ст. 63]. Выборы нового состава палат Парламента Респубцики Беларусь назначаются не позднее четырех месяџев и проводятся не позАнее тридцати Аней до окончания полномочий палат Аействующего созыва; внеочередные выборы палат Парламента проходят в течение трех месяџев со Аня Аосрочного прекращения полномочий палат Парламента [5, ст. 91]. Очередные выборы депутатов Мажилиса Республики Казахстан осуществляются не позАнее чем за два месяца до окончания срока полномочий действующего созыва Парламента, половина избираемых депутатов Сената переизбирается каждые три года. При этом их очереАные выборы Аолжны состояться не позАнее чем за Ава месяца Ао окончания срока их полномочий [6, ст. 51]. Выборы депутатов Парламента Молдовы проводятся не позднее чем в трехмесячный срок после истечения срока полномочий или роспуска Парламента предыдущего состава [9, ст. 61]. Полномочия парламента Республики Таджикистан прекращаются в день начала деятельности парламента нового созыва [10, ст. 48]. Очередные выборы в Верховную Раду Украины проходят в последнее воскресенье октября пятого года полномочий Верховной Рады Украины [11, ст. 77] .

Срок полномочий парламентов составцяет четыре года в Беларуси, Кыргызстане, Моцдове, пять мет в Азербайджане, Армении, Таджикистане, Украине, России; шесть иет в Казахстане. 
В статье не анализируется правовое регулирование иных принщипов избирательного права и организации и проведения выборов. Тем не менее отметим, что в конституџиях отдельных государств - участников СНГ предусмотрено: прямое или косвенное избирательное право (Беларусь, Казахстан, Таджикистан); свободное избирательное право (Азербайджан, Беларусь, Россия); свободное голосование (Молдова); тайное голосование (Азербайджан, Армения, Беларусь, Казахстан); мичное голосование (Азербайджан). Конституциями Кыргызстана и ТаАжикистана установлено количество подписей, которые необходимо собрать в поддержку кандидата.

Конституциями государств - участников СНГ в главах, посвященных выборам, преАусмотрены условия изменения срока полномочий в условиях военного положения.

Так, согласно ст. 101 Конституции Азербайджанской Республики установмено, что в случае, если ведение военных операџий в условиях войны не позволяет провести выборы Президента Азербайджанской Республики, то срок его полномочий продлевается до окончания военных операций. Решение об этом принимается Конституционным судом Азербайджанской Республики на основании обращения государственного органа, обеспечивающего проведение выборов (референдума) [3, ст. 101].

Национальное собрание Республики Армения не может быть распущено в период военного или чрезвычайного положения, а также тогда, когда возбужден вопрос об отрешении от домжности Президента Республики. В период военного и чрезвычайного положения выборы Национального собрания не проводятся, а срок полномочий Наџионального собрания продмевается до Аня открытия первой сессии Национального собрания, избранного вновь после окончания военного или чрезвычайного положения. В этом случае выборы Наџионального собрания проводятся в срок не ранее пятидесяти и не позднее шестидесяти дней после окончания военного или чрезвычайного положения [4, ст. 63]. Полномочия парламента Беларуси могут быть продмены на основании закона только в случае войны [5, ст. 93]; а, например, полномочия парламента Республики Момдова - органическим законом в скучае войны или катастрофы [9, ст. 63].

В заключение можно сделать вывоА, что посреАством применения конституџий государств - участников СНГ международных избирательных стандартов, равно как и при помощи системы национальных правовых избирательных стандартов, обеспечивается равный объем прав субъектам избирательных правоотношений, предоставцяются права, устанавливаются общие юридические режимы и иные составмяющие единообразного понимания и применения принципов и норм избирательного законодательства в наџиональном законодательстве [12]. Тексты конститущий государств - участников Содружества Независимых Государств устанавливают основные принщипы избирательного права и избирательного проџесса, что позволяет выделить взаимосвязь международно-признанных принципов избирательного права и избирательного процесса и национальных правовых избирательных стандартов, обеспечивающих их единообразное понимание и применение, а также отметить значительную вариативность их правового регулирования. 


\section{Библиографический список}

1. Алехина И.С. Избирательные стандарты Содружества Независимых Государств // Управленческое консультирование. 2016. № 9 (93). С. 60-68.

2. Конвенция о стандартах демократических выборов, избирательных прав и свобод в государствах - участниках Содружества Независимых Государств (Кишинев, 7 окт. 2002 г.). URL: http://base.garant.ru/1156220/

3. Конституция Республики Азербайджан от 12 нояб. 1995 г. // Собрание законодательства Азербайджанской Республики. 1997 г. № 1. URL: http://ru.president.az/azerbaijan/constitution

4. Конституция Республики Армения от 5 июля 1995 г. (с изм. от 27 нояб. 2005 г.) URL: http://www.parliament.am/parliament.php?id=constitution\&lang=rus

5. Конституция Республики Беларусь от 1994 г. (с изм. и доп. от 24 нояб. 1996 г. и 17 окт. 2004 г.). URL: http://www.pravo.by/print.aspx?guid=6351

6. Конституция Республики Казахстан от 30 авг. 1995 г. (с изм. и доп. от 2 февр. 2011 г.). URL: http://www.constitution.kz

7. Конституция Кыргызской Республики от 27 июня 2010 г. URL: http:/www.president.kg/ $\mathrm{ru} /$ konstitutsija/print

8. Конституция Российской Федерации от 12 дек. 1993 г. (с изм. от 21 июля 2014 г. № 11-ФКЗ). URL: http://www.consultant.ru/document/cons_doc_LAW_28399/

9. Конституция Республики Молдова от 29 июля 1994 г. (в ред. от 29 июня 2006 г. № 185-XVI). URL: http://www.presedinte.md/rus/constitution

10. Конституция Республики Таджикистан от 6 нояб. 1994 г. (с изм. и доп. от 22 июня 2003 г.). URL: http://www.president.tj/ru/taxonomy/term/5/112

11. Конституция Украины // Ведомости Верховной Рады Украины. 1996. № 30, ст. 141. URL: http://rada.gov.ua/uploads/documents/27396.pdf

12. Алёхина И.С. Правовые избирательные стандарты Российской Федерации и их реализация в субъектах Российской Федерации: На примере Северо-Западного федерального округа: дис. ... канд. юрид. наук. СПБ., 2005. 